\title{
Trick of Political Identity: Analyzing Appraisal System on 212 Movement Reunion in Online Media
}

\author{
Fahmi Gunawan
}

Institut Agama Islam Negeri Kendari, Kendari, Indonesia

fgunawanp@gmail.com

\section{Yopi Thahara}

Universitas Abdurachman Saleh, Situbondo, Indonesia

yopi.thahara@gmail.com

\section{Faizal Risdianto}

Institut Agama Islam Negeri Salatiga

faizrisd@gmail.com

DOI: http://dx.doi.org/10.18326/rgt.v12i1.62-80

\begin{tabular}{ll}
\hline Submission & ABSTRACT \\
Track: & $\begin{array}{l}\text { This study aims to investigate the appraisal system of the } 212 \\
\text { movement reunion in online media. Data were from the news of } \\
\text { Received: }\end{array}$ \\
"trick of political identity" in Tirto online media. To collect data, \\
the researchers used observation and taking notes. Content \\
Final Revision: \\
analysis was used to conduct the research. The result showed that \\
the attitude in the article consisted of appreciation (60\%), \\
judgement (23,33\%), and affect (16,67\%). Appreciation was the \\
Available online:
\end{tabular}$\quad \begin{aligned} & \text { dominant attitude in this research. It meant that the author wanted } \\
& \text { to assess and evaluate the } 212 \text { reunion movement and the object } \\
& \text { related to the movement. Meanwhile, the affect and judgement } \\
& \text { were used to assess the central figures in the 212 reunion } \\
& \text { movement. To write emotive feelings about the central figures and } \\
& \text { the events, the author dominantly used his own opinion, but he } \\
& \text { used the third person opinions to strengthen his opinion. } \\
& \text { Author: }\end{aligned}$




\section{INTRODUCTION}

Language and politics are closely interrelated because politics is realized through language (Geis, 2012). All political activities are carried out by using verbal language. Dealing with political discourse, before the general election, politicians will be careful to convey their ideas, opinions, or speech because their attitudes and expressions can be assessed by many people (Loader, Vromen \& Xenos, 2016). The expressions of attitude are not only possessed by the politicians, but also other professions such as journalists, reporters, etc. Journalists' expressions can be seen from their articles. Their articles can be objective or subjective. Their articles have to be objective because of their capacity as journalists that is neutral and objective. Meanwhile, their articles are subjective because the journalists are controlled by the owners (Sa, 2009; Gunawan \& Sumarlam, 2018)

The 212 movement at National Monument, Jakarta was peaceful demonstration headlined by the journalists (Kurniawan, 2018). The 212 movement was headlined on the printed or online media. The 212 movement was triggered by the massive demonstration against the Jakarta ex-governor, Basuki Tjahja Purnama because of his blasphemy (Gunawan, \& Kadir, 2017). Since the demonstration was held on December 2, the demonstration was called the 212 movement. The 2016 demonstration was addressed to demand justice for the blasphemy by Basuki Tjahaya Purnama, while the 212 movement in 2018 was aimed to gather the alumni of 212 movement in 2016 (Hadi \& Tirtosudarmo, 2016). The problems were the 212 movement 2018 was held in the political year and it was attended by the presidential candidate, Prabowo Subianto (PS). Hence, the 212 movement in 2018 attracted media's attentions. One of mainstream media in Indonesia that reported the news was Tirto Newspaper online.

In delivering news, especially the 212 reunion movement, a jurnalist is required to be as objective as possible in reporting the news, but some of the journalists can be subjective in reporting the news (Marchi, 2012). However the objectivity or subjectivity of the reporters in covering the news can be detected from their writings. The objectivity of the articles in the news can be detected from the use of lexico-grammar of the articles. In linguistics, the use of lexico-grammar can be examined by using appraisal which is part of Linguistic Systemic Functional.

Appraisal is simply interpreted as an assessment of something. Appraisal is used to assess people, things, situation, etc. In general, the assessment is divided into two; good or 
positive and bad or negative. The assessment to a person or object is relative. One thing is considered good by someone, but it can be considered bad by others. Because this discourse is positively responded by several linguistic experts, an appraisal theory is created. The appraisal theory was founded by Martin and Rose in 2003 and developed by Martin and White in 2005. Appraisal which is part of Linguistic Systemic Functional is a new theory, so that there is lack of references published. Some of the journal articles are cited in Martin and White's book as the reference in the literature review. Thus, the discussion of appraisal in this study will also cite from the same books and articles.

Martin and White (2005) defined appraisal as "evaluation of kinds of attitudes that are negotiated in texts, how strong are feelings that are involved, and how values are sourced to the readers." In short, we can assess the author's feeling and assessment through texts or articles that they write. In 2005, Martin and White stated that "Appraisal is about how evaluation is established, amplified, and targeted, or sourced." In that definition, Martin and White reiterated that Appraisal deals with an assessment.

Appraisal is classified into three domains by Martin and White (2005), namely attitude, graduation, and engagement. Attitude is related to feeling which includes an assessment of emotions, behavior of a person and assessment of an object. Graduation is a tool to measure person's emotional level, while engagement is the determinant of where and from which attitude arises. Attitude is a system of meanings that includes three semantic features which include emotion, ethics, and aesthetics (Martin and White, 2005). Emotion deals with someone's feelings that have naturally been shaped since someone was born. The dimension of emotion in the attitude is called affect. Ethics talk about a person's behavior that is realized in judgment, meanwhile aesthetics is a person's assessment of something which is realized in appreciation. The details of information can be seen in the following chart: 


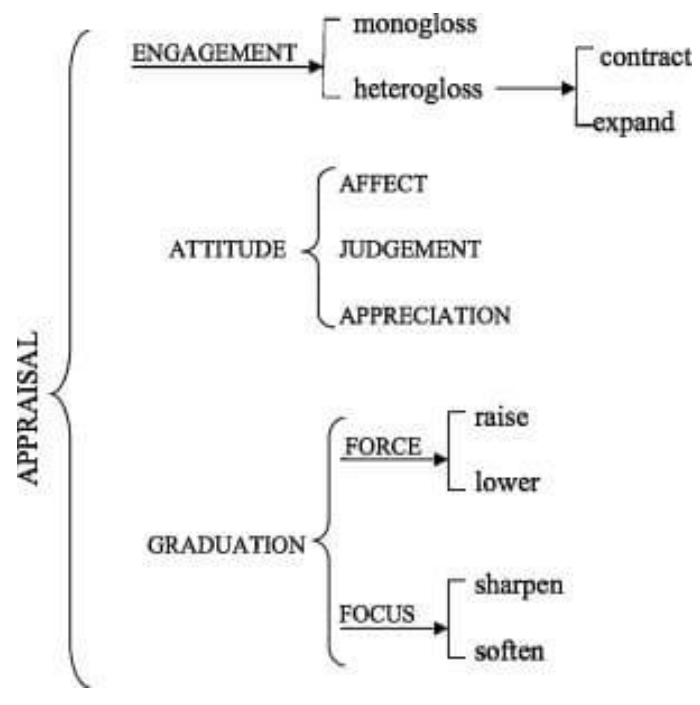

\section{Chart 1: \\ Appraisal System (Martin and White, 2005)}

Researches about appraisal system have been conducted by several researchers. However, the research only focused on novel (Dewi, 2015), state political speech (Sukma, 2018; Alvionita, 2018; Rohmawati, 2016), advertisment text (Yunus, 2018; Nugraheni, 2011; Tiani, 2017), information media on tourism (Suryaningtyas, 2018), application of appraisal in teaching (Mustadi, 2010) language evaluation (Panggabean \& Lestari, 2018) and online media. Research on the appraisal system particularly in online media has also been carried out by several researchers, such as Nur \& Hadi (2017), Pusparini, A., Djatmika \& Santosa (2017), Nazhira, R., Sinar, S \& Suriyadi, S. (2016), and Ellyawati (2016). They discussed the appraisal system from the different online newspapers and topics, but no one paper discusses the most phenomenal newsof 212 reunion movement in 2018 on Tirto as one of mainstream online media in Indonesia.Hence, this research aims to evaluate appraisal system on the news of 212 reunion movement in Tirto online media.

\section{RESEARCH METHOD}

This study uses a type of qualitative research using an embeded case study on the news of "Jerat Politik Identitas" "Trick of Political Identity" in Tirto online media during three months, October to December, 2018. Tirto online newspaper is chosen because it can attract the attention of the public eventhough it is a newcomer and regarded as the most read online news portal in the country competing with Detik, Kompas, Media Indonesia and Jawa Pos (cekaja.com). Currently, Tirto.id is considered as one of the online media that has deep 
and investigative characteristic (cekaja.com). To explain the phenomenon of appraisal included in the news text, this study utilizes the percentage of quantitative calculation data to support the description and explanation of appraisal system. This study uses the appraisal system theory of Martin dan White (2005) which is classified into three sections; they are, engagement, attitude and graduation. Therefore, to collect data, observation and note were used. Data were classified into primary and secondary data. Primary data are lexis or group of words containing appraisal system in the news. Secondary data are supporting data; such as data from authors' profile, website's profile, journals, or all information about the 212 reunion movement. To analyze data, the researchers used content analysis based on the theory of Martin dan White (2005).

\section{RESULTS \& DISCUSSION}

The news text trick of political identity contains 44 clauses and discusses the 212 reunion movement at National Monument, Jakarta. This text is classified as exposition text. Exposition is a text that described authors' opinions about events (Djatmika, 2018). It means that this political discourse is the authors' opinion about the 212 reunion movement that attracts world attentions. This text can be objective or subjective which depends on the authors' perspective. In fact, reporters are demanded to be objective in conveying the news. Exposition text is classified into two; analytic exposition and hortatory exposition. The structures of analytic exposition is thesis declaration, argumentation, and reiteration, meanwhile the structures of hortatory exposition are thesis, argumentation, and recommendation. Based on the research, this text is hortatory exposition text because it uses recommendation in the last part that is in the form of heterogloss (Djatmika, 2018).

\section{APPRAISAL SYSTEM}

Based on the data analysis, the appraisal system in the text is classified into three; attitude, graduation, and engagement. The attitude, graduation, and engagement in this research can be described as follow: 


\section{ATTITUDE SYSTEM}

Attitude deals with feelings which contain emotions, judgment to people's character, and appreciation to the things. Attitude is the system of meaning that is consisted of emotions, ethics, and aesthetics (Martin and White, 2005). Emotion deals with someone's feeling that is naturally shaped since someone is born. The dimension of emotion in the attitude is called affect. Ethics talk about someone's behaviour that is realized in judgment, and aesthetic is someone's assessment to thing that is realized in appreciation. Bock (2007) found the way to help researchers to distinguish the attitude. He used the keyword 'source' and 'target'. Source refers to affect that consist of participant (individual, group of people, or institution). Meanwhile, their behaviors or activities are the target of judgment. The targets of appreciation are object and process.

Based on the research, the text contained $5(16,67 \%)$ affects, $7(23,33 \%)$ judgmentss, and $18(60 \%)$ appreciation. The text containing affect and judgement mean that the author shows his feelings about the central figures in the 212 movement reunion. This emotions aimed at someone or a group of people involved in the movement. The author gave his assessment to Prabowo, Jokowi and the supporters. The assessments are reflected in the words, phrases and clauses made by the author. Meanwhile, the text containing appreciation was used to evaluate the event of 212 movement. The author assumes that the movement is such a political identity. Politic of identity is politic that deals with diversities which is based on the assumption of physical appearance, politic of ethnicity or primordialism, and the conflict of religion, belief, or language (Abdullah, 2019). Politic of identity emerges as a resistance from marginalized groups due to the failure of the government to accommodate minority interests. Positively, politic of identity is as a media of aspirations for oppressed people. Politic of identity is centered on the politicization of shared identity which is the main base of collective group. In Africa, political identity is well known as apartheid system (Daud \& Besar, 2017).In Indonesia, political identity tends to political beliefs and ethnic groups (Fauzi, Sudrajat, Affandi \& Raditya, 2018). Someone chooses a presidential candidate, for example, not based on a certain people but political beliefs and ethnic groups. In this case, Prabowo was supported by a structural Islamic community organization, such as Front Pembela Islam (FPI), Gerakan Nasional Pengawal Fatwa (GNPF) while Jokowi was supported by the goverment.

\section{AFFECT SUBSYSTEM}


Affect is an expression of feeling that is expressed positively and negatively. Positive expressions include expression of joy, happiness, confidence, enthusiasm. Negative expression is the expression of sadness which includes worry, boredom, prejudice, etc. The realisation of positive and negative expression can be directly or indirectly found in physical expression, unusual behavior and metaphor.

Based on the research data, there were 1 clauses of positive affect and 4 clauses of negative affects. Positive and negative affects were addressed to the central figures in the 212 reunion movement. The use positive affect can be seen in the data below:

1. Gaung dukungan politis itu tampak kala Rizieq Shihab, salah satu tokoh gerakan 212 yang hingga kini tak kunjung pulang ke Indonesia menyerukan "ganti presiden" pada pemilu melalui live streaming dari Mekkah.

The political support was seen when Rizieq Shihab, one of the leaders of the 212 movement who until now had not returned to Indonesia called for "change of president" in the 2019 election through live streaming from Mecca.

Data 1 showed that emotively the news author tend to support Prabowo and Sandiaga Uno as Indonesia President and vice president candidate. The support is represented by the phrase "menyerukan" (called for). The author wants the "change of president" in the upcoming presidential election 2019 in Indonesia.

Buya Syafii Maarif, et al (2010) stated that the issue of political identity emerged at 1970s in the United States of America, to face the issues of minority, gender, feminism, race, ethnic, and other social groups that were marginalized and persecuted. In its development, the scope of identity politic extends to issues of religion, belief, and diverse cultural ties. In Indonesia, identity politics is more related to issues of ethnicity, religion, ideology, and local interests that are generally represented by elites with their own articulations (Burhani, 2016). In his research, Ichwan (2016) revealed that the Islam Support Movement known as the 212 movement is a real example of the emergence of identity politic to demand justice by the majority of Muslims in Indonesia. This action was triggered by the statement of DKI Jakarta Governor, Basuki Tjahaya Purnama (Ahok), at Seribu Island on September 27, 2016 which was considered as "desecration of the Qur'an", "insulting the clerics" and even "insulting Moslem in the world". The movement demanded Ahok immediately to be accused and sentenced. This action was followed by various elements of the Moslem community with seven million people who mobilized from various regions in Indonesia. The Islamist movements then mobilized themselves, maximizing networks and using social media and 
"cyber army" by framing "desecration of the Qur'an and insults against cleric and Moslems". Sentiments of anti-non-Muslim and anti-Chinese united with the political agenda that was DKI Jakarta election. In such conditions, a "fatwa" (guidance) from the Indonesian Mufti Council emerged which stated that Ahok had carried out "desecration of the Qur'an and humiliation of mufti and Muslims". Ahok-Rizieq's feud later turned into the feud of the AhokMoslem, and even Christian feuds (religious missions) and Chinese (business) versus Muslims. It was then able to convince many Muslims to participate in the Islamic Supporting Movement 1, 2 and 3 (Abdullah, 2018).

Towards the presidential election, politic of identity shifted from the issue of religious to the issue of political choice in choosing the next president. The 212 reunion is now no longer purely a moral movement defending Islam. The 212 reunion movement has become a political opposition movement that wants to fight for power and wants the administration of President Jokowi to end in the 2019 presidential election. The Guidance Guards National Movement (GNPF) is the main actor in the movement. The GNPF consists of several mass organizations, such as the Front Islamic Defenders (FPI), Hizb ut-Tahrir Indonesia and others. Through Ijtima Ulama (mufti meeting), GNPF officially supports Prabowo and Sandi to be president and vice president.

However, the author also used negative affect to describe his dislike of Jokowi because it is considered an anti-Islamic government, Criminalization of Mufti, providing employment opportunities to Chinese people. These can be seen in the following data.

2. “... Siap pilih partai hasil ijtima ulama? Siap tenggelamkan mereka? Takbir! Takbir! Takbir!” seru Rizieq dengan suara lantang kendati ketua GNPF Ulama Yusuf Muhammad Martak Telah berjanji politik praktis tak akan ada dalam reuni 212.

“... Ready to choose the party from the result of Ijtima Ulama? Ready to sink them? Takbir! Takbir! Takbir!" exclaimed Rizieq in a loud voice despite the chairman of the GNPF Yusuf Muhammad Martak had promised that practical politics would not be in Reunion 212.

3. Sejumlah peserta Reuni 212 pun kedapatan mengelu-elukan nam sang calon presiden.

A number of 212 reunion participants were caught cheering on the name of presidential candidate.

The author used the phrase "tenggelamkan" (to sink) and "mengelu-elukan" to show his negative affect in the article. The phrase "tenggelamkan" was addressed to the other party out of the Ijtima Ulama result. The phrase "mengelu-elukan" refered to the name of Prabowo. The author intended to show that he wanted the change of the president in the upcoming presidential election 2019. 


\section{JUDGEMENT SUBSYSTEM}

Judgment is related to our assessment of others, especially in their attitudes, behavior, and character. Martin and White (2005) divided judgment into two, namely assessments oriented to 'social esteem' and assessments oriented to 'social sanction.' By Martin and Rose (2003), both terms are called personal judgment and moral judgment. Personal judgment is classified into swearing and praising, meanwhile moral judgment is classified into criticizing and admiring.

Based on the data, the judgements in the 212 reunion movement article were in the form of criticizing, admiring and praising. The author used negative judgment to criticize, while the author used positive judgment to admire and praise. For negative judgment, the authors used 3 clauses (10\%), while for positive judgment the author used 4 clauses $(13,33 \%)$. Positive judgment can be seen in the following examples.

4. "Itu pagelaran demokrasi. Tak ada politik identitas. Ini menunjukkan umat islam yang toleran," klaim juru bicara Badan Pemenangan Nasional (BPN) Prabowo-Sandi, Arief Poyuono.

"That's a democratic performance. There is no identity politic. This shows that muslim are tolerant, " Prabowo-Sandiaga winnning team spokesman, Arief Poyuono.

5. Ma'ruf Amin sebelumnya adalah tokoh kunci Aksi 212 pada Desember 2016 lalu.

Ma'ruf Amin previously was a key figure in 212 Movement in December 2016.

Positive judgements are addressed to the Muslim Indonesia and Ma'ruf Amin by the author. In the data 4 , the author gives positive judgement to the muslim in Indonesia. The positive judgement is delivered to show author's admirer to the Muslim in Indonesia. It refers to the movement that is held in peace by the muslim in Indonesia. The reunion 212 movement which was attended by militant members of the Social Justice Party (PKS), one of islamic political party in Indonesia, or the Gerindra Political Party that showed a tolerant attitude during the event. Meanwhile, the data 5 shows author's positive judgement to Ma'ruf Amin. The author gives positive judgement because Ma'ruf Amin is one of key figure in 212 movement in December 2016. The author believes that Ma'ruf Amin is able to influence many muslim in Indonesia.

\section{APPRECIATION SUBSYSTEM}

Appreciation deals with the assessment of objects such as books, films, houses, etc. To identify appreciation, Eggins and Slade as quoted in Bock (2007: 20) also make the same question with questions in judgment, namely "What do you do you think of that?". However, 
the expected answer to the question is not related to a person's behavior. Besides things, appreciation also includes an assessment of a phenomenon or condition. Martin and White (2005) stated that with appreciation, "we turn to mean construing our evaluations of things, especially things we make and performances we give, but also including natural phenomena what things are worth (how we value them)". Based on the research data, appreciation is the dominant attitude in the article about the 212 reunion movement. There are 18 (60\%) data that show the appreciation to the event, things, or object. There are $5(16,67 \%)$ data of positive appreciation and $13(43,33 \%)$ data of negative appreciation. The positive appreciation can be seen in the data bellow:

6. Kehadiran ratusan ribu orang dalam Reuni 212 menunjukkan gerakan ini mampu bertahan lama, tak seperti yang diprediksi banyak analis dan komentator.

The presence of hundreds of thousands of people in the 212 Reunion showed that this movement could last a long time, not as many analysts and commentators predicted.

7. Gerakan 212 yang akhirnya mampu menentukan hasil pemilu itu menunjukkan bahwa elit politik lihai memainkan politik identitas dengan melihat kondisi ekonomi dan perubahan kelas menengah dalam memandang islam.

The 212 movement which was finally able to determine the election results showed that the political elite was skilled at playing identity politic by looking at the economic conditions and changes the middle class in viewing Islam.

The data 6 and 7 show his appreciation to the 212 reunion movement. The author stated that this movement could last as in data 6 , because the movement started from the morning prayer and ended in the afternoon. A strong physical and having adequate food, drinks and medicines was unavoidable even though there were many volunteers who provided all the facilities needed. In addition, during the reunion, the activity took place peacefully. The peace situation was depicted in none of the facilities was damaged, even the plants on the roadside were safe.

On the other hand, the negative appreciations were addressed to the politic identity and the government. The negative appreciations can be seen in the following data:

8. Dalam diskusi yang sama,. Ia mengatakan jika gerakan-gerakan tersebut tak hanya menyebar persepsi bahwa pemerintah telah tidak adil terhadap umat islam di Indonesia...

In the same discussion, he said if the movements had been spread of the perception that the government had been unfair to Muslim Indonesia......

9. "Kita harus awas. Ini terjadi di depan mata kita, dan ini merupakan tanggung jawab kolektif bagi masyarakat Indonesia untuk mencerahkan [mereka].

We must be careful. This happened before our eyes, and this is a collective responsibility fo Indonesian people to enlighten them.

Data 8 showed that the author gave negative appreciation to the government. He used the phrase unfair to show the negative assessment to the government. The author wanted to convey to the reader that the government was unfair to the muslim in Indonesia. Meanwhile 
the data 9 showed that the author also gave negative appreciation to the identity politics in Indonesia. In this case, the identity politic influenced many people in Indonesia to implement Islamic law in Indonesia.

In this research, the use of negative appreciation is aimed to show that the author disagree with the 212 reunion movement because it contains political identity. The author said that political identity is rife in Indonesia in recent years with the emergence of conservative movements. The conservative movement used the issue of religion for the purpose of political power. It should be acknowledged that since the DKI Jakarta elections in 2017, conflicts between groups with identity attributes occurred. This group can be identified as conservative Islam and conservative nationalist groups. Conservative Islam as a religious group relies on scriptural verses about sacrifice to God, such as the doctrine of Jihad, for example, or views on the system of Islamic leadership or the Caliphate.

One of the supports on the implementation of Islamic Law is to prohibit choosing nonMuslim leaders during fighting against Ahok. Martin Van Bruinessen (2013) called this group a "conservative turn" in Indonesian Islam. The movement was led by the Front Islamic Defenders (FPI) and supported by PKS (one of political party in Indonesia), HTI, PERSIS, the Organization of Salafi Makassar Wahdah Islamiyyah (WI) which is the main force behind the rise of this group. This Islamic movement has demanded the implementation of Sharia law throughout Indonesia, and has entered into moderate Muslim organizations, Islamic political parties, universities, Islamic schools, and the media. The firmness of this movement continues to attack, especially by using social media. The phrase "The beauty of Islam without Shia, the Ahmadiyya and the Liberal Islam Network (JIL)," is currently used generally on Facebook to summarize this ideology. (Woodward\& Nurish, 2016). Azumardi Azra added that the conservative movement in Islam and politic of identity in Indonesia has been increasing because it has been influenced by Donald trump win in the 2016 presidential election in United States. This is because Donald Trump is able to use this identity politic to win the election in America (Azra, 2016). However, Azra revealed that this identity politic would not be effectively implemented in the upcoming 2019 elections. It is caused by many factors. One of them is the practice of progressive Islam and Nusantara Islam by followers of Muhammadiyah and Nahdatul Ulama, as well as the social cohesion of the Indonesian people is still very strong (Azra, 2016). 


\section{ENGAGEMENT SYSTEM}

In writing this news, the author did not only use his personal opinion about the 212 reunion movement, but also used others' opinions. The author used the opinions of others to protect himself from the haters. The author used people's opinions as hash tags and to imply what he wanted to convey to the public. Based on the data, there were $14(46,67 \%)$ heterogloss data and $16(53,33 \%)$ monogloss data. Monogloss is the sources of attitude that come from the author and heterogloss is the sources of attitude that come from others' opinion. The others' opinions refer to the opinions of Islamic studies experts and politicians in the 212 reunions movements including Alwi Shihab, Azumardi Azra, Habib Rizieq, Chairman of the Leimena Institute Jakob Tobing, Chairperson of the GNPF Ulama Yusuf Muhammad Martak, Spokesperson for the National Winning Body (BPN) ) Prabowo-Sandiaga, Arief Poyuono, Abdil Mughis Mudhoffir, Luqman-nul Hakim, and Diatyka Widya Permata Yasih, etc.

\section{GRADUATION SYSTEM}

Graduation is the strength of evaluation (Su, 2016; Wang, 2017; Surbakti, Sinar \& Setia, 2018; Zhang, 2018). Zhang (2018) stated that graduation in attitude enables authors to convey greater or lesser degrees of positivity or negativity, while in engagement graduation scales authors' conviction in their propositions. Graduation is concerned with resources for upscaling and downscaling the force and focus. The uses of graduation are classified into two subsystem, namely force and focus. Force subsystem consisted of swearing, metaphor, lexis attitude, and intensifier. Meanwhile, focus subsystem consisted of lower-raise word. In this research, force was the dominant graduation of the attitude with $30(100 \%)$ data. The form of graduation was in the form of attitudinal lexis - raise.

The nature of politic of identity was first introduced by L.A. Kauffman (2001). He traced the origins of identity politic to the student non-violent movement known as the SNCC (the Student Nonviolent Coordinating Committee), a civil rights movement organization in the United States in the early 1960s.Substantively, identity politics is associated with the interests of members of a social group who feel squeezed and eliminated by the domination of large currents in a nation or state. This is where the idea of justice for all becomes very relevant. In the United States, the initiators of the theory of identity politic postulate that it is 
the practice of extortion that builds awareness of the blackmailed group, especially the black community, Spanish-speaking people, and other ethnic groups who feel marginalized by the wheels of capitalism that favor to the owners of capital, certainly white people.

Based on Gutmann's view (2009), identity politics, which was also seen in the movement of Martin Luther King and Catholic bishops in America, was actually more driven by social justice arguments, not for religious reasons. In this perspective, the Black Muslim movement in America was not much different from other ethno-religious movements. Because they experienced unfair treatment and wanted to apply the principle of equality in the wider community, the idea of identity politics had become the topic of study among scientists by framing it in the various social theories. The extreme form of identity politics is the rise of ideas about separatism. This can be seen, for example, in Quebeck, whose speaks French and is cultured French, want to separate from the English-speaking Canadian nation.

Unlike America, identity politics in Indonesia arises because of issues of religion and ethnicity. This phenomenon can be found in the DKI Jakarta election which is often associated with the DKI Jakarta community as religious Betawi. The ban on the use of the National Monument (Monas) for religious activities by Ahok, sparked a number of Islamic groups to unite in order to produce their identity again by rejecting non-moslem candidate. The production of identity was success after the governor, Anis Baswedan allowed Monas to be used for social, cultural, and religious activities. This phenomenon which later made AnisSandi supporters considered as a group of political Islam and religious fundamentalism movements that did not accept diversity in society (Kasenda, 2018). On the other hand, other political groups play themselves with diversity of identities. Ahok-Djarot pair supported by PDIP, Golkar, PKB, PPP, Nasdem, and Hanura always used the campaign tagline to fight for diversity. It was manifested on November 19, 2017 at a parade of Bhineka Tunggal Ika or Kita Indonesian Action at the Hotel Indonesia Roundabout by Ahok-Djarot supporting parties. Some consider that the parade is to counteract the 411 action that was first carried out by the GNPF-MUI. The different groups reinforce the occurrence of political battles between ethnic minorities in the DKI Jakarta regional election. Anis Rasyid Baswedan as part of the Indonesian-Arab ethnic against Basuki Tjahaya Purnama as part of Chinese-Indonesia ethnic. 
Social group polarization as an impact on the 2017 DKI Pilkada influences mobilization of support based on political identity (Burhani, 2017).

Political identity was a viral headlined in several media including by Tirto.id online media because it emerged during the 212 reunion movement at National Monument, Jakarta. The movement was clearly aimed at fostering brotherhood among fellow 212 alumni in 2016, despite many comments from political observers who said that the movement was a political movement supporting Prabowo-Sandi presidential candidates. The 212 movement was said political movement because the event was attended by Prabowo. The movement was attended by more than 11 million people. All domestic and foreign mainstream media have published the event, so it was viral and was well-known throughout the world. In the level of discourse, political identity can be studied using Linguistic Systemic Functional, especially appraisal system. This research shows that Tirto.id's reporters use pattern $\operatorname{affect}^{\wedge}$ judgment ${ }^{\wedge}$ apreciation on the attitude system, heterogloss ${ }^{\wedge}$ monogloss on the graduation system and force ${ }^{\wedge}$ focus on the engagement system.

This research is not in line with the research conducted by Nazhira, R., Sinar, S., \& Suriyadi, S. (2016) about the appraisal system in the news text of Media Indonesia, Republika dan Kompas daylynational newspaper. The results of the study indicate that the attitude system in the Kompas daily uses affect ^^Appreciation^ ${ }^{\wedge}$ judgment patterns. Authors in Kompas daily tend to use affect patterns because they have a tendency to tell sensitive events, such as disasters, corruption, the economy, and crimes that cause concern in society. The author can feel how dangerous the problem is if it cannot be resolved properly. On the other hand, Media Indonesia and Republika newspapers use patterns of appreciation. Media Indonesia and Republika tend to predominantly use appreciation patterns because by giving a direct assessment in the form of appreciation, the writer wants to influence his readers on something (if a positive appreciation) or criticize something to be conveyed to the public (if negative appreciation). In addition, news writers at Koran Media Indonesia and Republika were interested in appreciating the objects or objects they reported. it is In line with Kompas, Jakarta Post in its opinion colomn also uses a pattern of affection, judgment and appreciationin reporting on the Munir case entitled "Pollycarpus out on parole: Resolve Munir Case"

In the news of the disclosure of the special treatment of convicted corruption cases, the author in kompas.com online media, used judgment system in his attitude system. This pattern 
is used to describe the existence of Artalita luxury cells in Pondok Bambu and describe them neutrally and in detail without any tendency to highlight one part of the case (Ellyawati, 2016) and not at all explain how the corruption case was carried out. This also means that Kompas.com is considered to have a deep and complete analysis, using a neutral and good vocabulary choice that is suitable for a comprehensive reader. Readers can listen to what is being discussed, how and why it happened. This is in accordance with the ideology of Kompas.com which is indeed careful in its choice of vocabulary and neutral in the presentation of its news coverage. The findings of this study are different from previous research findings that Kompas.com has a sharp analysis, objective in the assessment and uses good diction. This research was conducted based on the hypothesis of the appraisal system proposed by Martin and White. The data were in the form of 64,000 words containing news about images of 2014 Indonesian President Candidates taken from the Kompas online and Republika online. The data sources were Kompas online and Republika online. The research findings showed that Republika described the presidential candidates JW (Joko Widodo) and PS (Prabowo Subianto) in positive images. In contrast, Kompas described JW's positive images rather than negative. Meanwhile, PS was more depicted in negative than positive images. The finding also showed that Republika was more objective than Kompas in delivering data about the images of the presidential candidate. Republika described JW and PS in constructive images. JW was described as a fair individual and had a compact team. PS was considered as a capable pioneer who had love and certainty. Kompas described JW in a positive image. He was described as an individual that was strong, empathic, direct, inconspicuous, and close. Conversely, PS was broadly depicted in a negative image. He was described as a pioneer who was unconfident, enthusiastic and showing off that he was important. Republika was considered as more objective than Kompas in announcing the 2014 image of the Indonesian president's competitor (Abdulameer \& Noor, 2018). Finally, this study confirms that the use of certain pattern in a news text can be investigated using appraisal system and it reflects the author's ideology.

\section{CONCLUSION}

The author's expression in writing news, religious, social, cultural, and political discourse can be traced through the use of language. The realization of languages use can reflect the feelings or emotions of the author towards the main actors or central figures, events 
that are conveyed and the process of the events. The news writing about the 212 reunion movement that took place at the Jakarta National Monument in 2018 also illustrated the same thing. In systemic functional linguistics, the news consisted an appraisal system. Then, in writing the news, the author used (60\%) appreciation, (16,67\%) affect, and $(23,33 \%)$ judgement. The appreciation in this research is dominantly used to assess the events and objects related to the 212 reunion movement. The appreciation is also in the form of negative and positive appreciation. There are 16,67\% positive appreciation data and 43,33\% negative appreciation data. The appreciation is dominated with negative appreciation because the author wants to convey that he diagree with the identity politic in Indonesia because it is not appropriate to be implemented. Affect and judgment are used to assess people characters that involved in the 212 reunion movement. The affect and judgement are in the form of positive and negative. Positive affect in this research was 3,33\% data and negative affect was 13,33\% data. Meanwhile, positive judgement in this research was $13,33 \%$ data and negative judgement was $10 \%$ data. The use of judgement and affect in the article showed that the author try to position himself in the neutral position.

The sources of attitude in this research are coming from the author's opinion and others' opinion. In SFL technical terms, the author used more heterogloss $(46,67 \%)$ than monogloss $(53,33 \%)$. The source of attitude is dominated with monogloss system. It means that the auhtor dominantly used his own opinion to deliver his attitude about the 212 reunion movement. However, the author used third person opinion to strengthen his opinion about the 212 movement and objects related to the movement.

The level of attitude can be seen from the graduation of the attitude. The graduations in the appraisal system consist of focus and force. In this research, the graduation is dominated with the use of force with $100 \%$ data. The force is in the form of attitudinal lexis raised.

Finally, this research confirms that the news about the political Identity used patterns of appreciation^ ${ }^{\wedge}$ udgment ${ }^{\wedge}$ affect on the attitude systems, patterns of monogloss ${ }^{\wedge}$ heterogloss on the engagement system, and patterns of force ${ }^{\wedge}$ focus on the graduation systems. However, this study still has a number of limitations. This research is only focused on one online media that highlights the issue of the 212 reunion movement in 2018 at National Monument, Jakarta without comparing it to other online media. Therefore, further research can study the 
investigation of appraisal system on the news that is viral in the online media, such as the 212 movement.

\section{REFERENCES}

Abdullah, A. (2018). Membaca Komunikasi Politik Gerakan Aksi Bela Islam 212: Antara Politik Identitas dan Ijtihad Politik Alternatif. An-Nida', 41(2), 202-212.

Alvionita, R. (2018). Representasi Situasi Sosial dan Konstruksi Ideologi dalam Pidato Pelantikan Anies Baswedan. RETORIKA: Jurnal Bahasa, Sastra, dan Pengajarannya, 11(1), 57-67.

Azra, A. (2016). Transformasi Politik Islam: Radikalisme, Khilafatisme, dan Demokrasi. Jakarta: Prenadamedia Group dan PPIM UIN Syarif Hidayatullah Jakarta.

Bruinessen, V. (2013). Contemporary Developments in Indonesian Islam: Explaining the" Conservative Turn". Institute of Southeast Asian Studies.

Burhani, A. N. (2016). Aksi Bela Islam: Konservatisme dan Fragmentasi Otoritas Keagamaan. Jurnal Maarif Institute, 11(2).

Burhani, A. N. (2017). Ethnic minority politics in Jakarta's gubernatorial election. ISEAS Perspective, 39, 1-6.

Daud, M. A., \& Besar, J. A. (2017). Mahathir dan berakhirnya Dasar Aparteid di Afrika Selatan. Geografia-Malaysian Journal of Society and Space, 12(8).

Dewi, I. S. (2015). Appraisal dalam Novel Habibie \& Ainun The Power of Love.

Djatmika. (2018). Mengenal Teks dan Cara Pembelajarannya. Yogyakarta: Pustaka Pelajar

Ellyawati, H. C. (2016). Analisis Wacana Kritis Teks Berita Kasus Terbongkarnya Perlakuan Istimewa terhadap Terpidana Suap Arthalyta Suryani pada Media Online. Jurnal The Messenger, 3(2), 19-35.

Fauzi, A. M., Sudrajat, A., Affandi, A., \& Raditya, A. (2018, January). Maintaining Identity Political Culture In Indonesia. InJournal of Physics: Conference Series (Vol. 953, No. 1, p. 012185). IOP Publishing.

Geis, M. L. (2012). The language of politics. Springer Science \& Business Media.

Gunawan, F., \& Kadir, A. (2017, September). Lecturers' Language Style and Higher Students' Academic Emotions In Indonesia. In 2nd International Conference on Education, Science, and Technology (ICEST 2017). Atlantis Press.

Gunawan, F., \& Sumarlam, S. (2018, November). The Polemic of Kendari Beach Reclamation on Online Media (Critical Discourse Analysis). In International Seminar on Recent Language, Literature, and Local Cultural Studies (BASA 2018). Atlantis Press.

Gutmann, A. (2009). Identity in democracy. New Jersey: Princeton University Press.

Hadi, A., \& Tirtosudarmo, R. (2016). Migration, Ethnicity And Local Politics: The Case Of Jakarta, Indonesia. Populasi, 24(2), 23-36.

Https://tirto.id/jerat-politik-identitas-pasca-reuni-212-dbb4

https://www.cekaja.com/info/5-pengusaha-media-yang-bisa-jadi-inspirasi-bisnis/

Ichwan, M. N. (2016). MUI, Gerakan Islamis, dan Umat Mengambang. Ma'arif, 11, 87-104.

Kasenda, S. R. (2018). Tindak Pengancaman Dan Penyelamatan Wajah Anies Baswedan Dan Basuki "Ahok" Tjahaja Purnama. Jurnal KATA: Penelitian tentang Ilmu Bahasa dan Sastra, 2(2), 356-370. 
Kauffman, L. A. (2001). The anti-politics of identity. Identity politics in the women's movement, 23-34.

Kurniawan, B. (2018). Politisasi Agama di Tahun Politik: Politik Pasca-Kebenaran di Indonesia dan Ancaman bagi Demokrasi. Jurnal Sosiologi Agama, 12(1), 133-154.

Loader, B. D., Vromen, A., \& Xenos, M. A. (2016). Performing for the young networked citizen? Celebrity politics, social networking and the political engagement of young people. Media, culture \& society, 38(3), 400-419.

Maarif, A. S., Maarif, A. S., Ali-Fauzi, I., \& Panggabean, S. R. (2010). Politik identitas dan masa depan pluralisme kita. Centre for the Study of Islam and Democracy.

Marchi, R. (2012). With Facebook, blogs, and fake news, teens reject journalistic "objectivity". Journal of Communication Inquiry, 36(3), 246-262.

Martin, J.R. and Peter white. 2005. The Language of Evaluation. Appraisal in English. Palgrave Macmillan, New York.

Mustadi, A. (2010). Peningkatan Kemampuan Critical Reading (Cr) Melalui Penerapan Metode Appraisal System Dalam Pengajaran Bahasa Inggris. Jurnal STKIP, 9.

Nazhira, R., Sinar, S., \& Suriyadi, S. (2016). Apraisal Sikap Dalam Teks Berita Surat Kabar Nasional. Tutur: Cakrawala Kajian Bahasa-Bahasa Nusantara, 2(1), 1-14.

Nugraheni, Y. (2011). Sistem Appraisal Pada Teks Iklan Komersial Di Tabloid Nova. Parole: Journal of Linguistics and Education, 2(1 April), 45-58.

Nur, A. M., \& Hadi, A. S. (2017). Realisasi Appraisal Dalam Aspek Attitude Pada Media Online Instagram. Jurnal Sasindo UNPAM, 3(2), 15-24.

Panggabean, S., \& Lestari, F. D. (2018). Implementasi Apraisal Dalam Evaluasi Bahasa: Sebuah Ancangan Wacana Forensik. Melanesia, 2(1), 81-90.

Pusparini, A., Djatmika, D., \& Santosa, R. (2017). Analisis Sistem Appraisal Berita Proses Eksekusi Duo Bali Nine (Pendekatan Linguistik Sistemik Fungsional). Paramasastra, 4(2).

Rohmawati, I. (2016). Appraisal devices realizing attitudes in Barack Obama's inaugural speech. Vision: Journal for Language and Foreign Language Learning, 5(1), 27-56.

Suryaningtyas, V. W. (2018). Pemanfaatan Teori Appraisal Di Media Informasi Pariwisata Bilingual: Upaya Untuk Membangun Model Penerjemahan Berbasis Lsf.

Sa, E. S. (2009). Factors influencing freedom of the press in South Korea: A survey of print journalists' opinions. Asian Social Science, 5(3), 3-24.

$\mathrm{Su}$, T. 2016. Positive Discourse Analysis of Xi Jinping's Speech at the National University of Singapore under Appraisal Theory. Journal of Language Teaching and Research, 7(4): 796-801.

Sukma, Bayu Permana. (2018). Sistem Appraisal Pada Slogan dalam Kain Renta Kampanye Politik Bakal Calon Kepala Daerah Kabupaten dan Kota Bogor, Ranah: Jurnal Kajian Bahasa, 7 (2), 132-145.

Surbakti, E. B., Sinar, T. S., \& Setia, E. 2018. Engagement and Graduation in Text of the Law on Electronic Information and Transaction. KnE Social Sciences, 3(4): 295-305.

Tiani, R. (2017). Judgement Sebagai Sistem Appraisal dalam Iklan Kecantikan Visual Media Cetak. NUSA, 12(4), 256-264.

Umami, M. (2013). The Discourse System Recognized In The Jakarta Post's Opinion Coloumn Entitled "Polycarpus Out On Parole: Resolve Munir's Case" On December 05th, 2014.Register Journal, 6(1), 101-124.

Wang, M. 2017. A Study on College English Majors' Writings from the Perspective of Appraisal Theory. Theory and Practice in Language Studies, 7(1): 65-69. 
REGISTER JOURNAL

Vol. 12, No. 1, pp.62-80

p-ISSN: 1979-8903; e-ISSN : 2503-040X

DOI: http://dx.doi.org/10.18326/rgt.v12i1.62-80 Website: http://journalregister.iainsalatiga.ac.id/index.php/register/

Woodward, M., \& Nurish, A. (2016). Quo vadis FPI dalam aksi bela islam. Maarif: Jurnal Arus Pemikiran Islam dan Sosial, 11(2), 105-22.

Yunus, R. N. (2018). Sistem Apraisal Pada Teks Iklan Layanan Masyarakat Di Kota Tebing Tinggi. Jumant, 9(1), 105-113.

Zhang, Y. 2018. Attitudinal Analysis of President Xi's Remarks at Press Conference of BRICS Xiamen Summit from the Perspective of Appraisal Theory. Journal of Language Teaching and Research, 9(2): 385-390. 